\title{
Problems of Authority in Law and Anthropology: A Case Study on Aboriginal Australian Inheritance
}

\author{
Prue Vines*
}

\section{Introduction}

Problems of authority are the most significant problems in interdisciplinary work in law. Each discipline has its own epistemic community with a view of how truth is to be determined. In law this is called 'authority', so I use this terminology here. I offer as an example of problems of authority in interdisciplinary work a project carried out in Australia that used both anthropology and law to do research on the needs of Aboriginal people in Australia ${ }^{1}$ in relation to inheritance. For Aboriginal people in Australia the common law is not adequate as it fails to take into account a number of issues that are significant to them, including kinship, dealing with the body, passing on customary law knowledge and objects, among others. There is a double problem of authority here because the anthropology concerned is also about customary law, so that this project involves more than one form of interdisciplinarity. The question of authority is central to legal research, and lawyers are very familiar with it. Legal systems frequently recognise other legal systems' rules of authority. For example, if an Australian person makes a will that covers land in the Netherlands, the conflict of laws rules applied by Australian law recognises the Netherlands' rules about land law. This is done often, and there is no difficulty with recognising the relevant authority of the law. Interdisciplinary work in law and anthropology, as in this project, requires recognition of the rules of authority of both anthropology and law. In this project the double problem of authority arose because the relevant anthropology involved Aboriginal Customary Law. Australian common law does not recognise Aboriginal Customary Law as law (except in very particular cases), and therefore does not recognise its rules of authority in relation to inheritance as it might if it were to see it as law. So in this project anthropology (which has a different way of considering authority) was being used to illuminate the authority pattern of one legal system for the

* $\quad$ Professor, Director of First Year Studies, Co-Director, Private Law Research \& Policy Group Faculty of Law, The University of New South Wales, Sydney, Australia. Email: p.vines@unsw.edu.au.

1 There are two groups of Indigenous peoples in Australia: Torres Strait Islanders and Aboriginal people. The research was focused mostly on New South Wales, where the vast majority of Indigenous people are Aboriginal; hence the use of that word. 
purposes of another legal system. This, in my view, created an ironically irrational double problem of authority to be solved in the project.

\section{The Research Project}

The research project concerned the current needs of Aboriginal people in relation to the passing of property on death, and how they were impacted and could be supported by the common law of Australia. ${ }^{2}$ To explain this, some background is necessary.

\subsection{Background: Inheritance Law in Australia}

Australian common law is the general law of Australia. For inheritance this means that the doctrine of testamentary freedom gives a dominant role to wills. Where a person makes a will, that will distributes the whole of the estate. If a person does not make a will, or to the extent that their will does not exhaust their property, intestacy law will apply. The general intestacy legislation in all the jurisdictions emphasises the place of the spouse (defined broadly to include legally married, de facto and same-sex spouses) and the issue (defined by blood or legal adoption) over everyone else. ${ }^{3}$ If both spouse and issue are living, the estate will go to the spouse, or the majority will go to the spouse with a small proportion to the issue to the exclusion of all other relatives. The definition of 'children' and 'issue' (and indeed all relationships) in the common law is blood-based and focused on the nuclear family, and in intestacy is limited to first cousins. This is often inappropriate for Aboriginal people, who may have a quite different view of who are significant family members for the purposes of inheritance. ${ }^{4}$

If the law of intestacy or a will fails to make proper provision, the law of Family Provision or Testator's Family Maintenance allows certain eligible applicants, mostly family members, to apply to the court to alter the will or the intestacy provisions. ${ }^{5}$ In the same way that the rate of making wills is low for Aboriginal

2 The publications from this project include: Vines 2015, Vines 2013, Vines 2011; Vines 2007; Vines 2004 and Vines 2001.

3 Administration and Probate Act 1959 (ACT) Schedule 6; Succession Act 2006 (NSW) Chapter 4; Administration and Probate Act 1969 (NT) Schedule 6; Succession Act 1981 (Qld) Pt 1; Administration and Probate Act 1919 (SA) s72G; Intestacy Act 2010 (Tas); Administration and Probate Act 1958 (Vic) Pt 1 Div 6; Administration Act 1903 (WA) s14.

4 Aboriginal kinship rules are extremely complex, but are different from the common law rules in that they are less blood-focused, and kinship names such as 'child', 'mother', 'grandfather', etc., may apply to more than one person or generation of people or be defined in different terms from those in the common law: Keen, 1988 p. 80 . Having spent a long time in a particular community might also be regarded as establishing kinship, as the Northern Territory Law Reform Committee has observed: NTLRC 2003, p. 21.

5 Family Provision Act (FP) 1969 (ACT); Succession Act 2009 (NSW); Family Provision Act 1979 (NT); Succession Act 1981 (Qld); Inheritance (Family Provision) Act 1972 (SA); Administration and Probate Act 1958 (Vic); Testators Family Maintenance Act 1957 (Tas); Inheritance (Family and Dependant's Provision) Act 1972 (WA). 
people, ${ }^{6}$ applying for family provision is extremely rarely done by Aboriginal people.

\subsection{The Methodology}

The methodology required for the project included legal doctrinal research, anthropological scholarship and semi-ethnographic qualitative research. The first phase included an assessment of the common law of inheritance against the circumstances of Aboriginal people. The second phase required literature reviewed from anthropology, and the third phase involved spending time with Aboriginal people, observing and listening to them talking about their needs. This is where I went and asked Aboriginal communities what they wanted. It was not complex ethnographic research, but only required that I be willing to wait, listen and ask what they thought was important. What was effective was that I recognised the community members' authority, in particular that of the women elders. In doing so I also had to organise the meetings with the community in such a way as to give them control. This was even more important because Aboriginal people in Australia have been studied extensively and are very suspicious of such studies, and they are used to the legal system being against them. ${ }^{7}$ So I would organise a meeting, and then I would just have to wait until community members turned up. Usually a meeting set for 10 a.m. would be attended from about 2 p.m., and it might go on for several hours. I would have to let the young men blame me for the wrongs the legal system had done to Aboriginal people, and acknowledge that they were right. Then often the young men would leave, and the women elders would stay. I would listen to them explaining what the big issues were for them, while they discussed it among themselves and then turned to me to tell me what they thought I should know.

\subsection{The Results}

The results of this research showed that for Aboriginal people, intestacy law as it stood was highly problematic for a number of reasons. First, there was legislation specifically for Aboriginal people in Queensland and Western Australia, which

6 A very small number of Aboriginal people, between 2 and 6\%, makes a will in Australia. This compares with 55-59\% of the non-Indigenous population. Most studies of non-Indigenous people suggest a rate of 54 to $55 \%$ of adults over the age of 18 . This may be increasing. The 2013 survey by Newspoll for the NSW Trustee \& Guardian showed a rate of 59\%. In 2012, 79\% of Queenslanders over the age of 35, and $98 \%$ of those over 70 had a current will: Wilson \& Tilse 2012. Intestacy rates considered as the rates of grants of letters of administration on intestacy were 6\% in New South Wales in 2003; and 13\% in Tasmania in 2005. This leaves a significant number of deaths for which no grant of any kind is made. More recently, the Victorian Law Reform Commission reported 7.75\% of grants involved total intestacy in 2010-11: VLRC 2013. The rate in Australia is a great deal higher than that in either the United Kingdom (37\%: Humphrey et al. 2010) or the United States (31\%: DiRusso 2009-2010).

7 The rate of Aboriginal imprisonment in Australia is appalling. The Indigenous population makes up $2.5 \%$ of the population, but $26 \%$ of the prison population. This means most Aboriginal people know people in gaol: www.lawcouncil.asn.au/lawcouncil/images/LCA-PDF/ Indigenous_Imprisonment_Fact_Sheet.pdf (accessed 2 April 2016). 
was discriminatory and inappropriate. This has now been repealed. Second, there is a mismatch of kinship structures in the mainstream legal system as opposed to Aboriginal Customary Law. This is important because kinship creates obligations. The first point was apparent from doctrinal analysis; the second point was clear from a comparison of the legislation with the anthropological work on kinship. The problems identified by listening to the women elders were not quite as expected. They were quite aware of the problems of passing property onto the correct people because of kinship issues, but this was not what they saw as the biggest issue. The big issue for them was managing the burial and disposal of the body. Every single community that I visited reported that they had had at least one very big dispute about the disposal of a body that had split the community, and in some cases, the split remained even after twenty years or more. In some of the more urban groups it was felt that dispute resolution rules that operated in the past were no longer viable, and they needed another way to manage the disputes. They were extremely interested in the fact that the executor (the person named in the will as the person who should manage the estate) had the right to decide what to do with the body. They also explained that Aboriginal funerals are more expensive than others' because so many people need to attend, and they go on for a long time and often need another ceremony with all the same people a year later. Lastly, there were a small number of people in each group who were concerned about the passing on of customary law knowledge or ritual objects in a way that did not require secrecy to be violated.

Anthropologists have told us that in many Aboriginal groups ${ }^{8}$ before colonisation, inheritance was almost non-existent ${ }^{9}$ because when a person died their dwelling and their very few possessions would be burned and the group would not go back to that spot for at least a year. Ritual objects would in most cases have already been passed to the proper person, and as there was no money there was no need to pass that. Land was held communally, so it was not inherited on death. Obligations then as now were created by kinship. ${ }^{10}$

Traditionally, Aboriginal Customary Law applied to every facet of an Aboriginal person's life. This continues to apply to some groups, but with growing urbanisation, Aboriginal people may continue to observe some aspects of Aboriginal Customary Law rather than others, in the same way that a Muslim who moves countries will continue to observe Shari'a law except where the new country forbids it. It is not true that Aboriginal people who no longer live on their traditional lands have no connection to that land or to their Aboriginal Customary Law. ${ }^{11}$ To

8 There are many different Aboriginal cultures: there are some 300 Aboriginal nations and 600 languages in an area larger than Europe. Each culture is different, although there may be some similar patterns in some groups. For this reason it is difficult to legislate for Aboriginals as if they are one group.

9 Anthropology sources on inheritance and death include: Berndt 1974; Bohemia \& McGregor 1991; Hiatt 1969; Hiatt 1962; Bell 1998; Rowley 1970; see also for material told by Aboriginal people themselves, Mattingley \& Hampton 1988.

10 Elkin 1974, p. 144.

11 Vines 2003. 
whom Aboriginal Customary Law applies is sometimes controversial: the definition of an Aboriginal person for some time has included a person of Aboriginal descent (no percentage specified), who identifies as Aboriginal and is accepted by the Aboriginal community as Aboriginal. ${ }^{12}$ Further, Aboriginal Customary Law is not a single monolithic system covering the whole of Australia. It varies for each group. Some patterns can be discerned that were useful for the project. The first of these is that it is clear that kinship dictates obligations. ${ }^{13}$ Kinship relationships are extremely complicated and may involve up to eight patterns of kinship for each person, each determining certain obligations. Whether living traditional lifestyles or not, ideas about kinship remain one of the most enduring cultural ideas that any individual has, and there is strong evidence that Aboriginal people's kinship ideas survive urbanisation and modernisation.

\section{Characterising the Interdisciplinary Nature of This Work}

This project was interdisciplinary in nature, requiring use of both law and anthropology. Law is a discipline in that it is based on a system of 'self-referential communication', creating both a common social identity among the members of the discipline and a factual base that is the content of the communication. ${ }^{14}$ Another way of saying this is that disciplines may be 'epistemic communities. ${ }^{15}$ The same may be said of anthropology. Of course, the boundaries between disciplines are changeable over time, and disciplines may be recognised at one time period and not at another. A range of different taxonomies of interdisciplinarity exist, ${ }^{16}$ but most ultimately seem to think of it in terms of the level of integration between the disciplines. Interdisciplinary work, then, works across or between disciplines, ranging from what may be called multidisciplinary work, ${ }^{17}$ where the disciplines sit side by side, are juxtaposed or sequenced as compared with interdisciplinary work that is more integrated so that the disciplines are integrated, interact or blend, or perhaps the work 'calls upon sources from different disciplines towards the goal of solving questions posed within multiple disciplines'. ${ }^{18}$

Here is a definition of the discipline of law:

Taekema and van Klink set out five types of interdisciplinarity - heuristic, which uses another discipline for inspiration; auxiliary, where the lawyer defines a problem that cannot be answered by law alone; comparative, where each discipline is equally important; perspectivist, where the work switches between the disciplines and, lastly, integrated: Taekema \& van Klink 2011, p. 17. Other attempts to describe and taxonomise include: Siems 2009; Klein 2010; Miller 2015.

Miller 2015, p. 3.

Miller 2015, p. 3. 
Monodisciplinary research in law consists in the collection, analysis and systematization of legal norms promulgated by the legislature and applied by the courts, in many cases together with an assessment thereof on the basis of legal or other (eg political, ethical or sociological) standards. ${ }^{19}$

This definition clearly slides into interdisciplinariness or at least multidisciplinariness in the parentheses. Disciplines can also be compared according to their concepts, methods, their object, what they think the problem is and what their research goals are. ${ }^{20}$ Thus for law in the western sense, central concepts are courts, parliament, legislation, regulation, cases, judges, lawyers, etc, but for anthropology, central concepts might be cultural patterns, language, social mores, how kinship is thought of, and so on. Legal methods include textual analysis of various kinds that are quite distinct from the textual analysis done by a literary linguist or an anthropological linguist. The object of study for law is contested, but it might be legal validity or the impact of law. Research goals in law can be descriptive or normative in terms of legality, coherence, etc. Anthropological research goals are more likely to be explanatory, and methods are more likely to be ethnographic and produce descriptive or explanatory outcomes rather than normative ones. Considering the effect of the common law on Aboriginal inheritance required me to draw on data from both law and anthropology. This meant, first, drawing on the common law that was currently in place and governing inheritance for Aboriginal people. This involved the usual analysis of cases and legislation to determine in what circumstances Aboriginal people were covered and what the law said about them. To consider the impact of this common law I had to go to anthropological sources of both theoretical and ethnographic kinds ${ }^{21}$ to determine the social/ cultural positions of Aboriginal people as affected by the common law. But that material also indicated that the social/cultural positions were actually matters of Aboriginal Customary Law.

\section{$4 \quad$ Interdisciplinarity and Authority}

Aboriginal Customary Law has its own hierarchies of authority that differ from the Australian common law hierarchies of authority. It became evident that to respond to the needs of the Aboriginal people the Australian common law had to find a way to take account of the Aboriginal Customary Law and its authority requirements.

To do this I had to be able to evaluate it in both disciplines. I had to be able to draw the anthropological knowledge into the legal domain and make it operate there. The project therefore raised all the issues discussed above, namely that law and 
anthropology have different goals, methods and substance. The difficulty in such a project is to make a meaningful connection between the different disciplines. For this project I drew on two of Van Klink and Taekema's five factors affecting interdisciplinary connections: ${ }^{22}$ truth value/validity and translatability. I chose these two as the most relevant for my project. Truth value or validity is a significant issue for interdisciplinary work because it raises problems of authority or rigour. This is an epistemological question for the disciplines. The relevant question is 'why should I believe?' For this project this question had to be answered both for law (in two forms) and for anthropology.

The problem of translatablility is a fundamental one in interdisciplinary work. Translatability refers to the extent to which any concept can be moved to the other discipline without change or loss of meaning. This is important if comparison is to be meaningful. Obviously, in languages the problem of translatability varies - the words 'girl' in English and maedchen in German are almost interchangeable. But this is not always the case.

In the project a cultural translation problem existed between non-Indigenous and Indigenous people in Australia because the English legal word 'children' may not refer to the same group of people in an Aboriginal family as in a non-Indigenous family. To illustrate, the common law legal definition of children in inheritance law refers to the biological offspring of the parent where the parent was married to the other parent of the child, and the word refers only to the first generation. ${ }^{23}$ To this, legislation has added adopted children ${ }^{24}$ and ex-nuptial children. ${ }^{25}$ However, in some Aboriginal kinship groups, the word children will refer to the biological children of the parent and to his or her same-sex sibling's biological children and to adopted children. ${ }^{26}$

The patterns of western inheritance law (and ideas of who is in the family) are lineal, with time going from past to present to future, and blood focused. Aboriginal culture's view of kinship is much less blood focused, and sees time as a circle rather than a line, so that one may see certain relationships being repeated. ${ }^{27}$ Kinship names such as 'child', 'mother', 'grandfather', etc, may apply to more than one person or generation of people or be defined in different terms from those in the common law. Having spent a long time in a particular community might also be regarded as establishing kinship. ${ }^{28}$ Aboriginal individuals may have as many as eight 'skin groups' each having different patterns of kinship and therefore of obligation. If one does not grow up in that community it is almost impossible to develop an authoritative understanding of those patterns.

Van Klink and Taekema 2011 refer to five factors that affect interdisciplinary 'connections': truth value/validity; explanatory/understanding; fact/value; translatability; and whether it involves fundamental or applied research.

23 Hill v Crook (1873) LR 6 HL 265 at 282-3 per Lord Cairns; Brydall 1703.

24 For example, Adoption Act 2000 (NSW) s 95.

25 For example, Status of Children Act 1996 (NSW), s 5.

26 Bell 1993, Appendix 2; Keen 1988, p. 80; Sutton 1998.

27 Keen, 1985.

28 NTLRC 2003, p. 21. 
Translatability can also be thought of as incommensurability when language is not the issue. In this project, understanding of differences such as those in the kinship was vital to connecting the anthropology with the impact of the law. The kinship problem obviously meant that if Aboriginal people were going to be governed by the common law the wrong people were going to inherit. This looks as if it is only about translatability, but in Aboriginal Customary Law, kinship determines obligation, so it also raises authority issues, as discussed below.

\section{A Double Problem of Authority}

Truth value/validity concerns how we know something is valid or true in this discipline. This is a problem of authority, based on the epistemological question of how we know things, and, more importantly, the question of when we can accept that a proposition is true. The meaning of truth in different disciplines can vary in that, for example, legal truth is that determined by a court of law, and anthropological truth may be that developed by a well-recognised ethnographer. ${ }^{29}$ This research raised a double problem of authority beyond that raised by some interdisciplinary work because it involved two types of law (Australian law and Aboriginal Customary Law) and anthropology.

\subsection{Authority in Common Law}

In each legal system there are rules used to determine, first of all, whether something is law. This is a question of authority. At common law in UK and Australia a statement is a law if it meets requirements such as being passed by parliament and given the Royal Assent, or being a decision made by a judge in a court. The doctrine of precedent determines the authority of different judges' decisions. ${ }^{30}$ The level of authority of the law in a common law court depends on a complex matrix of factors, including the point the court is on the hierarchy and the level of persuasiveness of the judgments. Civilian courts such as those of Germany or the Netherlands differ in that their authority as lawmakers is officially less than that of common law courts, but their authority is still a matter partly of position in the hierarchy and persuasiveness of argument. Legislation is similarly authoritative, depending on the level of the body that passed it - local government legislation is generally less powerful than national legislation, for example.

\subsection{Authority in Anthropology}

An anthropologist is generally regarded as authoritative with respect to some area or group of people when he or she has spent significant time with them and published material on the group. There is a long tradition of big names in Australian anthropology - A.P. Elkin, R.M. and C. Berndt, Rowley, Hiatt and Bell, among 
others. They are not all in agreement. In particular, there was a period when women were left out of the picture, ${ }^{31}$ which was part of the reason the Hindmarsh Island affair was so difficult. Anthropology makes authority its central work in that the anthropologist has to 'write accurately about the ideas and relationships of the Aborigines of a particular area'. ${ }^{32}$ The accuracy requirement means that the ethnographer must locate the person who is most able to identify a particular idea or relationship. Only if that has been done adequately can the work be seen as authoritative. And the ethnography can only be as good as its sources - if some particular source, such as women, is left out it cannot be complete. As Bell points out, one of the first group of women in the Hindmarsh Island case (which is discussed later) was Doreen Kartinyeri, an anthropologist herself, and an experienced researcher: 'She would take the word of a respected elder over that of written sources. 33

\subsection{Authority in Aboriginal Customary Law and the Clash with Common Law Authority}

In Aboriginal Customary Law what is truth or law may be what Elders agree and teach, what has been told in dance or story or paintings through the 40-60,000 years of continuous history Aboriginal culture can claim. ${ }^{34}$ Aboriginal traditional culture is oral, based on stories and expressed in dance and paintings - evidence that lawyers have difficulty with. The common law cultural idea that writing is more reliable than oral tradition applies here. In our legal system we are much happier with a document than with a story told to us. We get even more anxious when the story is told to us 'as told to me by my grandfather'. We forget that even in our own traditions there have been very reliable oral traditions, e.g. the AngloSaxon culture had a pattern of alliteration with a break in the middle of a line, ${ }^{35}$ which had a very strong effect on its memorability and the likelihood of it being repeated verbatim. In some cases the failure of the common law to recognise that there is authority in Aboriginal Customary Law leads it to rely instead on what is, ultimately, second-hand evidence, that of anthropologists whose work is more acceptable to the common law because it has been written down.

Aboriginal culture is oral, and secrecy is built into most Aboriginal culture. ${ }^{36}$ The customary law works in such a way that people in the group may not even know about an item or story or place until they are judged qualified to know about it. So in a famous Australian case called the Hindmarsh Island ${ }^{37}$ case, which illustrates the clash extremely well, a bridge was to be built from the mainland to an island.

Brock 1989.

Maddock 1984, p. 213.

Bell, 1998,p. 397.

ABC News Report 2016.

E.g. Beowulf.

Bell 1989.

The Hindmarsh Island case is really a series of cases including Chapman \& Anor v Tickner \& Ors (1995) 55 FCR 316; see also Chapman v Luminis Pty Ltd (No 5) [2001] FCA 1106-;Wilson \& Ors v The Minister for Aboriginal and Torres Strait Islander Affairs \& Anor [1996] HCA 18; (1996) 189 
A group of Aboriginal Ngarrindjeri women claimed that where the bridge would land was a sacred site for 'secret women's business'. Another group of Ngarrindjeri women said they had never heard of the sacred site. This was taken as evidence that the first group had made it up. The first group of women refused to reveal the secret information except to a woman, whom the Minister for Aboriginal Affairs refused to appoint. A Royal Commission held that the secret women's business was fabricated. This is a classic example of a failure to understand authority by the general legal system, who did not understand the pattern of secrecy and knowledge in Australian Aboriginal culture: ${ }^{38}$

Knowledge is embedded in social relations: those of gender, age, land affiliation, trade, ceremony, kinship and marriage. In this system access to knowledge is restricted and passed by word of mouth, and people move closer to the core of sacred knowledge as they demonstrate competence. Such a system needs clearly articulated rules for the transmission of knowledge (ie to whom, when, under what circumstances, with what consequences and so on), and these rules must be accepted by participants in the system. This is what I have called the etiquette of an oral culture....Like good scholars everywhere, Ngarrindjeri cite their authorities and sources when they tell stories. ${ }^{39}$

In a massive irony, the evidence that was regarded as definitively showing that the secret women's business did exist was the evidence of deceased white (mostly) male anthropologists who had left documents in the South Australian museum that showed that the first group of women were right. ${ }^{40}$ Ultimately, a Federal Court judge ruled that there had been no fabrication. ${ }^{41}$ The irony is that once written down, the rightful custodians of such information lose control over it: they have lost their authority. In this case, the very vindication of their authority completely undermined it.

Aboriginal people, of course, were present in Australia before the British colonised it. However, Aboriginal Customary Law was and is recognised only marginally in Australian law. ${ }^{42}$ It is taken into account in sentencing, ${ }^{43}$ for assessment of damages in tort law ${ }^{44}$ and for native title. ${ }^{45}$ In all these cases it is treated as a

CLR 1; Kartinyeri \& Anor v Commonwealth of Australia [1998] HCA 22; 195 CLR 337. See also Aboriginal Law Bulletin 1996.

38 Bell 1998.

39 Bell 1998, p. 376.

40 Bell, 1998, Papers of Norman Tindale from the 1930s to 1970s.

41 Chapman v Luminis Pty Ltd (No 5) [2001] FCA 1106

42 For general discussion of the issue see ALRC 1986; LRCWA 2006.

43 As part of the circumstances of the individual who is to be sentenced: e.g. Jadwin $v R$ (1982) 44 ALR 424; Western Australia $v$ Richards (2008) 37 WAR 229; also in restorative justice when practiced with juvenile Aboriginal people: Braithwaite 1989.

44 For example, Napaluma $v$ Baker (1982) 29 SASR 192.

45 Native title in Australia was first recognised in 1992 by the High Court of Australia in Mabo $v$ Queensland (No2) (1992) 175 CLR 1. It is now regulated by the Native Title Act 1993 (Cth). Native title requires a continuing connection with the land. 
question of fact that the law recognises and applies to common law. Otherwise, the common law of Australia applies. Therefore, unless something else is done, the common law of inheritance applies to Aboriginal people in Australia, most commonly the law of intestacy, which is based on culturally inappropriate views of kinship for them.

Many of these issues are created by the failure of Australian common law to recognise the authority of Aboriginal Customary Law. Indeed, it is still very common for Aboriginal Customary Law to be seen as 'culture' or 'religion' and therefore as not due the deference that another legal system might be given. This raises the interesting paradox that Aboriginal Customary Law has been studied by anthropologists rather than by comparative lawyers. This also creates a problem in that the definition of law used by anthropologists has tended to be wider ${ }^{46}$ than that used by lawyers, who are more likely to define law in terms of what may be coerced. This problem has lessened with the increased exposure to common law created by the burgeoning employment of anthropologists in relation to native title since the Mabo decision. However, the fact that Aboriginal Customary Law is not recognised as law by Australian law creates a problem of authority that is different from the problem of, for example, English law applying Netherlands law. There we use conflicts of laws rules to solve our problem of authority. We do this precisely because we do recognise that Netherlands law is law. This does not apply in relation to Aboriginal Customary Law, since the founding myth of Australian common law was terra nullius 'land belonging to no one' ${ }^{47}$ Although this has been overturned by Mabo, the overturning is most commonly thought of purely in relation to native title. Recognition of Aboriginal Customary Law as having a system of authority remains alien to the common law.

\section{Resolving the Double Problem of Authority}

Ultimately, it became clear that in this research project on inheritance all the hierarchies of authority could be made effective. First, once the anthropological evidence was used to establish the customary law along with the responses of the participants, there was no further need to consider anthropological authority issues. The important dynamic was the different levels of authority in Aboriginal Customary Law and Common Law. The project made it clear that we could resolve the clash of authorities in two ways, which also solved the problems Aboriginal people were concerned about in relation to inheritance. the behaviour of a particular society regardless of any sanction....

47 This myth allowed the Crown not only to be sovereign, but also to own the land. Land in Australia is still held by feudal tenure of the Crown. Although terra nullius was overturned by Mabo $v$ Queensland (No2) (1992) 175 CLR 1, the feudal tenure structure remains in place for all land ownership except native title. 
The first way was by legislation that actually recognised the authority of customary law in cases of intestacy of Aboriginal persons. This legislation has now been passed in New South Wales and Tasmania. Where an Aboriginal person has died intestate, it allows his or her Aboriginal group to submit a plan of their customary law regarding inheritance, and then gives that legal force. ${ }^{48}$ This solves the kinship problem and the passing of property and guardianship of children, but in turn it may create another problem of authority - Aboriginal communities generally operate by consensus and will wait until everyone agrees to come to a decision. But if people do disagree they may not tell the Supreme Court Registrar so. The legislation is not unproblematic, although it is helpful and will solve many of the problems that have been occurring, where there has simply been ad hoc distribution and children might have been inappropriately removed.

The second way to resolve this problem of authority is by using the will. The will, as a common law instrument, is capable of transmitting the intention of the testator or testatrix in a form that the common law sees as authoritative. Far from being a capitulation to common law for Aboriginal people, the unique properties of the will in a common law system where it covers the entire estate and operates to exclude intestacy mean that as each will is drafted for a particular individual, it is possible to meet their needs under both customary law and common law in the one document. Wills and the doctrine of testamentary freedom are a very old part of the Australian common law's inheritance from English law. The will can be used to enfold and protect customary law, thus giving the customary law the protection of a common law doctrine. The appointment of executor is a very significant part of this, because in Australian law the executor has the right to deal with the body, ${ }^{49}$ which was so much the concern of the women elders. The other advantage of wills is the possibility of drafting a will to match the kinship view of the testator rather than the general law's view of who is kin. This has also meant educating lawyers in changing their drafting practices somewhat in order to make culturally appropriate wills. ${ }^{50}$ Because it gives the testator the power to determine what will happen themselves, this solution is the better way.

\section{Conclusion}

The problem of authority is at the heart of interdisciplinary research. In a short article this cannot be covered in detail. In an age of specialisation, knowledge of an area is likely to be deep rather than wide, and when we seek to move across disciplines we make mistakes because we are not qualified to know what is authoritative and what is not. Anthropology makes this problem of authority its central work; but when I as a lawyer attempt to 'do' anthropological work from a legal

50 There has been a very large pro bono push to make wills for Aboriginal people across Australia, often using the Handbook developed by this project: Vines 2015. 
background (despite several years of undergraduate education in anthropology), I may have a double problem of authority in attempting to link law and anthropology, particularly because the law involved is of two kinds - common law and customary law. Despite this, it was possible to do this research and conclude that in this case the problem of authority could be satisfactorily resolved both in the research and in the outcome for Aboriginal people.

\section{References}

\section{ABC News Report 2016}

Australian Broadcasting Commission News Report,' Recent discoveries of Aboriginal cave paintings have been dated at 40,000 years': www.abc.net.au/news/2010-05.31/ megafauna-cave-paintings-could -be-40000-years-old/847564 (accessed 11th March 2016).

\section{Aboriginal Law Bulletin 1996}

'Chronology of the Kumarangk/Hindmarsh Island Affair' Aboriginal Law Bulletin 1996 No 64.

\section{ALRC 1986}

Australian Law Reform Commission, The Recognition of Aboriginal Customary Laws 1986.

\section{Bell 1993}

Diane Bell, Daughter of the Dreaming, 2nd ed, Sydney: Allen \& Unwin, 1993.

\section{Bell 1998}

Diane Bell, Ngarrindjeri Wurruwarrin: A world that is, was, and will be, Melbourne:

\section{Plt \& Berndt 1999}

R.M. Berndt and C.H. Berndt, The World of the First Australians: Aboriginal Traditional

Life Past and Present, Canberra: Aboriginal Studies Press, 5th ed., 1999.

\section{Berndt 1974}

R. M. Berndt, Australian Aboriginal Religion Leiden: EJ Brill 1974.

\section{Bohemia \& McGregor 1991}

Jack Bohemia and William McGregor, 'Death Practices in the North West of Australia' 15(1-2) Aboriginal History 1991 p. 86.

\section{Braithwaite 1989}

John Braithwaite, Crime, Shame and Reintegration, Cambridge: The University Press 1989.

\section{Brock 1989}

P. Brock (ed), Women, Rites and Sites: Aboriginal Women's Cultural Knowledge, Sydney: Allen \& Unwin 1989.

\section{Brydall 1703}

John Brydall, Lex Spuriorum, London, 1703 , New York: rep. Garland Publishing.

Carrithers et al. 1990

M. Carrithers, A. Bary, I. Brady, C. Geertz, R. Keesing, 'Is Anthropology Art of Science?' 31(3) Current Anthropology 1990 p. 263 [and Responses and Comments and Reply].

Cross \& Harris 1991

R. Cross and J.W. Harris, Precedent in English Law, $4^{\text {th }}$ ed., Oxford: Clarendon Press, 1991. 


\section{DiRusso 2009-2010}

A. DiRusso, 'Testacy and Intestacy: the dynamics of wills and demographic status ' (2009-1010) 23(1) Quinnipiac Probate Law Journal 36.

\section{Elkin 1976}

A.P. Elkin, The Australian Aborigines, Sydney: Angus and Robertson, 5th ed., 1976.

\section{Glenn 2004}

H. Patrick Glenn, Legal Traditions of the World, 2nd ed., Oxford University Press 2004.

\section{Hiatt 1962}

L Hiatt, 'Local Organisation Among the Australian Aborigines' 32 Oceania 1962 p. 267.

\section{Hiatt 1969}

B Hiatt, 'Cremation Practice in Aboriginal Australia' 7(2) Mankind 1969 p. 104.

\section{Humphrey et al. 2010}

A Humphrey et al., Inheritance and the Family, National Centre for Social Research, UK, 2010.

\section{Keen 1985}

I. Keen, 'Definitions of Kin' 41 Journal of Anthropological Research 1985 p. 62.

\section{Keen 1988}

I. Keen, 'Kinship', in R.M. Berndt and R. Tonkinson (eds), Social Anthropology and Australian Aboriginal Studies Canberra: Aboriginal Studies Press 1988.

\section{Klein 2010}

Julie Thompson Klein, 'A Taxonomy of Interdisciplinarity' in J T Klein, C Mitcham and R Frodeman, (eds)., The Oxford Handbook of Interdisciplinarity 2010.

\section{LRCWA 2006}

Law Reform Commission of Western Australia, Aboriginal Customary Laws: the interaction of Western Australian Law and Aboriginal Law and Culture, Perth: Quality Press 2006.

\section{Maddock 1984}

Kenneth Maddock, 'Aboriginal Customary Law' in Peter Hanks and Brian KeonCohen (eds)., Aborigines and the Law Sydney: George Allen and Unwin 1984.

\section{Mattingley \& Hampton 1988}

Christobel Mattingley and Ken Hampton (eds), Survival in our Own Land: Aboriginal Experience in South Australia since 1836 told by Nungas and others Adelaide: Wakefield Press 1998.

\section{Miller 2015}

J.T.M. Miller 'Methodological Issues for Interdisciplinary Research' https://community.dur.ac.uk/postgraduate.english/index_files/ (accessed 24 October 2015).

\section{NTLRC 2003}

Northern Territory Law Reform Committee, Background Paper 1, Aboriginal Communities and Aboriginal Law in the Northern Territory, Darwin, 2003.

\section{Rowley 1970}

Charles Rowley, The Destruction of Aboriginal Society Canberra: Australian National University Press 1970.

\section{Siems 2009}

Mathias M Siems, 'The Taxonomy of Interdisciplinary Legal Research' J of Commonwealth Law and Legal Education 2009 p. 5-17.

\section{Sutton 1998}

Peter Sutton, Native Title and the Descent of Rights Perth: National Native Title Tribunal, 1998. 


\section{Taekema \& van Klink 2011}

Sanne Taekema and Bart van Klink, 'On the Border, Limits and Possibilities of Interdisciplinary Research' in B.M.J. van Klink and H. S. Taekema (eds) Law and Method: Interdisciplinary Research into Law Tubingen: Mohr Siebeck, 2011, p. 7-32

\section{Vines 2001}

Prue Vines 'Wills as Shields and Spears: the failure of intestacy law and the need for wills for customary law purposes in Australia' 5(13) Indigenous Law Bulletin 2001 p. 16.

\section{Vines 2003}

Prue Vines, 'When Cultures Clash, Aborigines and Inheritance in Australia' in G. Miller (ed) Frontiers of Family Law Farnham: Ashgate 2003.

\section{Vines 2004}

Prue Vines, 'Consequences of Intestacy for Indigenous People in Australia: the passing of property and burial rights' 8(4) Australian Indigenous Law Reporter 2004 p. 1.

\section{Vines 2007}

Prue Vines, 'Drafting Wills for Indigenous People: pitfalls and considerations' 6(25) Indigenous Law Bulletin 2007 p. 6.

\section{Vines 2011}

Prue Vines, 'Making Wills for Aboriginal People in NSW' 49(8) Law Society Journal 2011 p. 72.

\section{Vines, 2013}

Prue Vines, 'The NSW Project on the Inheritance Needs of Aboriginal People: solving the problem by making culturally appropriate wills' (2013) 16(2) Australian Indigenous Law Review 2013 p. 18.

\section{Vines, 2015}

Prue Vines, Aboriginal Wills Handbook: a practical guide to making culturally appropriate wills for Aboriginal people, 2nd ed., NSW Trustee \& Guardian, 2015 (free download (copyright waived) available at http://www.tag.nsw.gov.au/wills-for-aboriginalpeople.html).

\section{VLRC 2013}

Victorian Law Reform Commission, Succession Laws Consultation Paper 13: Intestacy, (2013) [2.23].

\section{Weingart 2010}

Peter Weingart, 'A Short History of Knowledge Formations' in J T Klein, C Mitcham and R Frodeman, (eds) The Oxford Handbook of Interdisciplinarity 2010.

\section{Wilson \& Tilse 2012}

J Wilson and C Tilse, Will-making in Queensland: Report to the Office of the Public Trustee of Queensland, 2012. 
